\title{
Chapter 11 \\ Resilient and Nonresilient Students in Sweden and Norway-Investigating the Interplay Between Their Self-Beliefs and the School Environment
}

\author{
Jelena Radišić and Andreas Pettersen
}

\begin{abstract}
Using TIMSS 2015 data and a person-centred approach, the chapter focuses on academically resilient students in Norway and Sweden in grade eight. The self-belief profiles of academically resilient students compared with the nonresilient groups (i.e., low SES/low achievement, high SES/low achievement and high SES/high achievement) are investigated. Further, we evaluated the characteristics of the classroom environment for each of the profiles. After accounting for student SES and achievement, personal characteristics, advantages and disadvantages in the classroom and the school environment, we identified distinctive student profiles that might be more prone to risk. In the context of the equality-inequality paradigm, recognition of these profiles can strengthen the possibility to reduce the gap in battling different aspects of inequality across social groups. Concurrently, although we distinguish the same student groups across Sweden and Norway, their distribution within the countries differs. The latter results contribute to the ongoing debate on the dissolution/unification of the Nordic model, especially regarding particular trends within the Swedish education system.
\end{abstract}

Keywords TIMSS $\cdot$ Students' self-beliefs $\cdot$ Students at risk $\cdot$ School environment

A strong relationship between students' socio-economic background and school achievement has been reported in various cases (Nilsen, Blömeke, Hansen, \& Gustafsson, 2016). Research has shown that across different educational systems,

\footnotetext{
J. Radišić $(\square) \cdot$ A. Pettersen

Department of Teacher Education and School Research, University of Oslo, Oslo, Norway

e-mail: Jelena.radisic@ils.uio.no
} 
students from families with more social and economic resources (SES) may have higher chances of succeeding in school (e.g., Nilsen et al., 2016; OECD, 2018; Xie $\&$ Ma, 2019). Similarly, students from the lower socioeconomic spectrum are more likely to perform poorly at school and have less of a chance to complete secondary and tertiary education (see Reardon, 2011). This strong relationship between student background and school achievement implies that educational systems may not be equally ensuring the success of every child (Doll, 2013; Pianta \& Walsh, 1998).

However, despite the reports of a consistent relationship between SES and achievement, many students with socioeconomically disadvantaged backgrounds still succeed in school (Masten, 2014). Some are even among the top-performing students in their schools. These students are commonly labelled as academically resilient because they are successful in school despite being situated in an environment linked to poorer outcomes (Martin \& Marsh, 2006). Trying to understand more about resilient students and what might have contributed to their success is regarded as critical to both educators and policy makers. Indeed, targeted actions and support could ensure that more students can succeed in school, equipping them with the different tools needed to obtain positive outcomes. Also, such analyses can provide valuable insights of the possible differentiation between resilient and nonresilient groups because the latter may include students who face different challenges and difficulties and who often lack support in battling adverse outcomes.

The current study adds to this field by focusing on the distinct differences between resilient students (i.e., high-achieving students with low SES) and nonresilient student groups (i.e., low-achieving students irrespective of SES and successful students with high SES) in connection to their self-beliefs related to mathematics (i.e., confidence, interest and value) and sense of school belonging. Our primary assumption rests on the premise of a person-centred approach of the heterogeneity of the student population, which is often overlooked when we observe the relationship between different variables alone (Bergman \& Trost, 2006). We take this idea a step further by examining whether distinct belief patterns can be extracted across resilient and nonresilient student groups or whether some belief patterns can be regarded as unique to a particular student category (e.g., resilient students). Furthermore, we investigate the school and classroom environment of students with distinct selfbelief patterns and how these relate back to students initially categorised as resilient or not. To address these issues, we utilise the 2015 data from the Trends in International Mathematics and Science Study (TIMSS) for students in grade eight in Norway and Sweden. The multiple-group analyses within a broader person-centred perspective will enable us to observe different nuances across the resilient and nonresilient student groups in both countries (Morin, Meyer, Creusier, \& Biétry, 2016).

\subsection{Academic Resilience as a Mirror of Systems' Inequality}

Although earlier definitions of resilience have focused more on observing resilience as an individual characteristic (Masten, 2018), the literature has slowly moved in the direction of the view that resilience can originate from factors external to the 
individual. This idea allows for converging towards the so-called risk and protective paradigm, which explores those influences that can predict resilience (e.g., family or school environment; Abelev, 2009; Franklin, 2000; Masten, 2014, 2018; Rutter, 2006). Over time, the complexity of the lenses used to understand resilience has only increased, introducing the ecological view (Bronfenbrenner \& Morris, 2006), developmental-systemic perspective (Masten, 2018) or view of resilience as a dynamic process of interaction between the contexts and the individual's agency (Hernandez-Martinez \& Williams, 2013). At the same time, these multiple lenses have not aided in finding a more unified operationalisation of resilience (Sattler \& Gershoff, 2019). Despite this, the construct tends to travel across disciplines, especially in the social sciences and humanities (Masten, 2018).

Within the educational milieu, resilience is often discussed in the context of academic resilience or educational resilience. As such, it is described as 'heightened likelihood of success in school (...) despite environmental adversities' (Wang, Haertel, \& Walberg, 1994, p. 46). Hence, academically resilient students are those who succeed in school even though they are subjected to unfavourable surroundings or despite having a disadvantaged background. According to Sattler and Gershoff (2019), the different definitions of resilience can be divided into two main categories. The first focuses on 'the processes between risk and protective factors in promoting or hindering positive adjustment', while the latter focuses on 'the criteria usedfor judging competence following adversity' (Ibidem, 2019, p. 88). Furthermore, two different criteria are used in distinguishing resilient from the nonresilient students. These include (1) doing better than peers experiencing similar risks (lowthreshold resilience) and (2) doing as well as peers not experiencing risk (high-threshold resilience).

Over the past few years, constructs similar to academic resilience have emerged. One such example is academic buoyancy, which refers to students' ability to deal with everyday setbacks, challenges and pressures, such as exam pressure, low grades and difficulties related to schoolwork (Martin \& Marsh, 2008). Thus, although resilience is related to more 'chronic' adversities, buoyancy is related to 'everyday hassles and coping' (Martin \& Marsh, 2008). Independent of its conceptualisation, academic resilience can be seen as a by-product of inequality in the school system. Per the definition, resilient students are subjected to inequality because they come from socially, culturally or economically disadvantaged milieus. Thus, resilience is often viewed in light of and related to the concepts of educational (in)equality and equity (e.g., OECD, 2018; Reyes, Elias, Parker, \& Rosenblatt, 2013). Across the literature, the terms are frequently used in both a similar and dissimilar fashion, provoking some disagreements regarding its meaning (Espinoza, 2007). According to Espinoza (2007), equity is usually 'associated with fairness or justice in the provision of education', while equality is associated with sameness in treatment. Rather than striving for a unique and straightforward conception of equity and equality in education, Espinoza (2007) argues that multiple definitions are needed. His 'equality-equity model' aims to clarify and differentiate educational equity and equality regarding the different stages and features of the educational process, allowing for a broader perspective of the equity-equality continuum. Similarly, academic resilience can also be related to the different stages and features 
of the educational process and, thus, can be associated with different conceptions and definitions of equity and equality.

Data from the international large-scale assessment studies (ILSA), such as TIMSS and the Programme in International Student Assessment (PISA), are often used to investigate equity in education from a variable-centred approach. In these, students' gender, socioeconomic status, immigrant background or school characteristics are related to achievement as a measure of equity (e.g., Agasisti, Avvisati, Borgonovi, \& Longobardi, 2018; Erberber, Stephens, Mamedova, Ferguson, \& Kroeger, 2015; Nilsen et al., 2016; OECD, 2018; Zhu, 2018). From this perspective, more equitable school systems are those in which less variance in student outcomes can be attributed to their background.

In recent years, using data from the ILSAs researchers have also focused on investigating resilience in countries around the world. These investigations provide understanding of the factors that underlie students' success across sometimes very different systems (e.g., Erberber et al., 2015; OECD, 2018). In these studies, academically resilient students are defined in a somewhat different fashion; they are viewed as scoring above a certain threshold in achievement and below the specified limit on students' background measures (i.e., related to the social, economic and cultural resources of the students' homes) and are thus very much aligned with the earlier described categorisation by Sattler and Gershoff (2019). However, the criteria for judging competence within ILSAs can take both a national and international perspective. Although both views have their merits, they do produce different population draws distinguishing between resilient or nonresilient students (OECD, 2018). In the current study, the former is chosen under the assumption that it provides a more comparative approach across different reference groups within the national systems we observe.

\subsection{Factors Linked to Resilience in Mathematics}

With the notion that academic resilience occurs at the crossroads of the individual, family and school (Doll, 2013), numerous studies have tried to map out both student and school characteristics that may support resilience. At the student level, positive student attitude towards mathematics, confidence, high self-esteem, commitment and sense of control are reported to endorse resilience (Martin \& Marsh, 2006; Sandoval-Hernández \& Białowolski, 2016; Wayman, 2002). Similarly, Kalender (2015) argues that resilient students have mostly positive attitudes towards school and their teachers compared with low-achieving students. The latter, in comparison, perceive that they could not be successful even if they tried. Also, resilient students show confidence in using their resources and ask for help when it is needed. They establish and preserve positive relationships with their teachers and peers (Eisenberg et al., 2003; Lessard, Butler-Kisber, Fortin, \& Marcotte, 2014). The quality and nature of these relationships are consistently reported among the essential protective elements needed to succeed (Doll, Zucker, \& Brehm, 2004). At the same time, 
teacher confidence in student performance was also associated with higher chances of academic success (Sandoval-Hernández \& Białowolski, 2016). Yet although the comparisons established across the studies are usually between resilient students and low achievers, they do not differentiate between low achievers from the higher and lower SES bands. Thus, because particular constituents are attributed to the resilient students compared with nonresilient ones, further exploration is needed to explore these student categories regarding SES.

In a position paper by Ungar, Connelly, Liebenberg, and Theron (2019), access to supportive relationships, experiences of social cohesion with others and access to material resources are listed as examples of what schools can do to support student resilience. These school characteristics are sustained even when student background is controlled for (for details, see Borman \& Dowling, 2010; Perry \& McConney, 2010; Wiberg, 2019). School climate has been steadily seen as a school feature that fosters the conditions for optimal learning environments, which lead to positive student outcomes (Kyriakides, Creemers, Antoniou, \& Demetriou, 2010; Maxwell, Reynolds, Lee, Subasic, \& Bromhead, 2017). Among its key aspects are the school's emphasis on academic success (Hoy, Tarter, \& Hoy, 2006) and a safe and orderly climate (Wang \& Degol, 2016). Although both constructs are mutually connected (Hoy et al., 2006; Thapa, Cohen, Guffey, \& Higgins-D’Alessandro, 2013), they are also linked to students' outcomes and engagement (Martin, Foy, Mullis, \& O'Dwyer, 2013; O'Brennan \& Furlong, 2010; Wang \& Degol, 2016). However, some authors do caution on the need for exploring these constructs' differential effects across low- and high-SES schools (Lee \& Smith, 1999) and countries (Sandoval-Hernández \& Białowolski, 2016).

ILSAs also contribute with some crucial insights. Using the TIMSS 2011 data, Erberber et al. (2015) observe the factors associated with resilience in 28 education systems participating in TIMSS. They find that students' educational aspirations, valuing of mathematics and experiencing less frequent bullying emerged as predictors of resilience in several education systems, coupled with students' beliefs about their teachers' confidence in their abilities. At the school level, across the board, schools' emphasis on academic success and schools having a lower percentage of economically disadvantaged students could be linked to resilience (Erberber et al., 2015). The authors, however, conclude that despite some similarities in their crosscountry analyses, there is no universal recipe that could be applied to all the 28 examined cases. Similar results are obtained in PISA 2015 in connection to the field of science. Here, the school socioeconomic profile and the disciplinary climate in school are the two school factors most frequently associated with resilience in the national context, and students' motivation to achieve the best they can was the most critical student factor linked to it (OECD, 2018). Although one of the significant affordances of the ILSA data lies in its opportunity for cross-country comparisons, one can argue for a more focused approach in the selection of the countries involved in such analyses. Thus, although no universal recipes are found when examining particular relationships (e.g., Erberber et al., 2015), a more focused choice can be a first step. 


\subsection{Provision of Education in Norway and Sweden}

After World War II, both Norway and Sweden—as well as other Nordic countriessaw significant advances in the introduction of comprehensive school systems. This system allowed all children and young people to be enrolled in a standard structure across different stages in the educational system (Telhaug, Mediås, \& Aasen, 2006). The policy differed from some other Western countries, such as Germany, France, the Netherlands or the UK. In the early days, equality of education for all students rarely extended beyond ages 10 or 11, corresponding to grades four and five within the system of compulsory public schooling. At the same time, students from the upper social classes often did not attend the state schools (Telhaug et al., 2006).

According to Blossing, Imsen, and Moos (2014), the Nordic model of education has been, historically speaking, 'based on a vision that schools should be inclusive, comprehensive, with no streaming and with easy passages between the levels'. (p. 1). Also, they argue that in the Nordic countries 'school (...) was considered to be an extension of the state's duty to provide equality of opportunity for all members of society (...) regardless of social background, abilities, gender and place of living' (Blossing et al., 2014, p. 1). Such vision has provided a chance for all students to develop their potentials and aims, given the goal to supply all with the same quality of education provision. At the same time, the principle also envisions that competent students, irrespective of their background (i.e., low or high SES), are assumed to be among the most successful. The main goal of the comprehensive school system in the Nordic countries as a whole has been to abolish the class-based society.

In both Sweden and Norway, compulsory education is free and ranges from grades one through ten (Norway) and one through nine (Sweden). In Norway, upper secondary school (in Norwegian videregående skole/opplaring) is voluntary but legally accessible to all students, while in Sweden, upper secondary school (in Swedish gymnasieskolan) is voluntary and free. Thus, at both levels, there is equality of opportunity, providing all students with access to prescribed educational levels, irrespective of whether they use the opportunity or not. At the same time, over the years, notable differences have appeared between the systems in Norway and Sweden. The latter has gone through extensive decentralisation reforms (Blossing \& Söderström, 2014). The change has been coupled with more severe marketisation and privatisation practices (Lundahl, 2016) and because of which Sweden has somewhat lost its position as one of the most equitable school systems (Lundahl, 2016; Skolverket, 2013).

In addition, the importance of students' socioeconomic backgrounds has increased. Although Wiberg (2019) shows that both the school context and the students' background has had an impact on the students' TIMSS results in Sweden, Broer, Bai, and Fonseca (2019) observe a substantial increase in the gap between high- and low-SES students' achievement in mathematics. In contrast, an overall decrease in the achievement gap in mathematics for the same period was reported for Norway (Broer et al., 2019). The results in PISA also demonstrate this shift. The results from the 2018 cycle show that for students in Sweden, 13.2\% of the variation 
in mathematics performance can be explained by SES, which is similar to the OECD average (OECD, 2019). In PISA 2012, a similar trend can be found-10.6\% in Sweden and $14.8 \%$ in OECD countries. In Norway, this was $8.4 \%$ in 2018 and $7.4 \%$ in 2012, respectively. Despite the differences in the described trends, the results indicate that this unfavourable background does contribute to the poorer outcomes of some students. It also illustrates what Espinoza (2007) describes as the (in)equality on average across the social groups relative to student output and survival in the system. The former indicates students' adverse outcomes are linked to differentiation in the available resources between the SES groups, while the latter implies a higher dropout rate of the lower SES band (Farrell, 2013). Conversely, although such trend analyses are informative in keeping track of different educational processes in the system, what they often disregard is the heterogeneity of the student body (e.g., diversity in self-beliefs), even if students belong to the same SES categories. Focusing on such distinctive features may aid in providing a more differentiated portrait of students and their outcomes, even across settings.

\subsection{Current Study}

Against the background described in the previous sections, we focus on distinct differences between academically resilient students and nonresilient student groups (i.e., low-achieving students irrespective of SES and successful students with high SES) in connection to their self-beliefs related to mathematics (i.e., confidence, interest and value) and their sense of school belonging. Following this, we investigate the school and classroom environment of students who have distinct self-belief patterns and how these relate to students initially categorised as resilient or not. For this purpose, we utilise TIMSS 2015 grade eight data for Norway and Sweden within the context of the person-centred approach (Bergman \& Trost, 2006) and multiple-group analyses (Morin et al., 2016). Both these methods enable us to better understand the different nuances across the student body in Sweden and Norway, not disregarding diversity in the applied thresholds when discerning resilient and nonresilient students (Sattler \& Gershoff, 2019), either from a national or crossnational standpoint (OECD, 2018). Two research questions are central to this investigation:

(1) What are the characteristics of academically resilient students compared with the nonresilient groups in connection to the students' perceived confidence in mathematics, them valuing and liking mathematics as a subject and their sense of school belonging? Here, we expect optimal self-belief profiles to attract both resilient students and other high-achieving students (Erberber et al., 2015; Kalender, 2015; Martin \& Marsh, 2006; Sandoval-Hernández \& Białowolski, 2016; Wayman, 2002), while the low-achieving students, irrespective of the risk factors, will be more frequently found in the disfavourable self-belief profiles. 
(2) What are the typical features of the school and classroom environment of students with distinct self-belief patterns, and how do these relate to students initially categorised as resilient or not? Based on previous studies, we postulate optimal self-belief profiles, saturated by resilient and non-risk-achieving students will be conducive to environments with strong school emphasis on academic success (Erberber et al., 2015; Hoy et al., 2006) and will be in a safe and orderly climate (Wang \& Degol, 2016) with less frequently reported experiences of bullying (Erberber et al., 2015).

In addition to these two questions, we will observe whether the same patterns are discernible in both Sweden and Norway (Sandoval-Hernández \& Białowolski, 2016) given the latest developments in the Swedish education system (Lundahl, 2016; Skolverket, 2013). Finally, we explore to what extent the patterns are transferable across low-achieving students given their differences in SES (Lee \& Smith, 1999).

\subsection{Methods}

\subsubsection{Participants}

In the analyses, TIMSS mathematics 2015 data for grade eight in Norway and Sweden were used. The TIMSS framework implements strict sampling procedures at the country level, here following a two-step sequence. In the first step, a school sample is selected from a complete list of schools. The targeted population is grade eight students. In the second step, a random class is chosen in each of the schools (for details, see Mullis \& Martin, 2013). The full data set for Norway totalled 4733 students and 4090 in Sweden, respectively.

Finally, to build the sample used in this investigation, both data sets were further stratified into four student categories. The academically resilient category comprised students from the lowest $25 \%$ on the SES scale who are at the same time among the $25 \%$ highest achieving students in the TIMSS mathematics test within their own country. The three comparison categories involved the failing under risk students (the lowest $25 \%$ on SES/the lowest $25 \%$ in mathematics achievement), the low-achieving group (the highest $25 \%$ on SES/the lowest $25 \%$ in mathematics achievement) and the nonrisk achievers (the highest $25 \%$ on SES/the highest $25 \%$ in mathematics achievement). The four categories were obtained for each country separately. Please see Table 11.1 for more details.

All later analyses were performed with these four categories as the principal sample constituents. At the same time, by defining these four categories in such a way, we could include the criteria of both low and high resilience thresholds (i.e., 'doing better than peers experiencing similar risks' and 'doing as well as peers not experiencing risk') in our investigation (Sattler \& Gershoff, 2019). 
Table 11.1 The four student categories comprising the final sample

\begin{tabular}{l|r|c}
\hline & Sweden & Norway \\
\hline Academically resilient group & 94 & 109 \\
\hline Failing under risk students & 511 & 463 \\
\hline Low-achieving group & 78 & 136 \\
\hline Nonrisk achievers & 459 & 531 \\
\hline Total & 1142 & 1239 \\
\hline
\end{tabular}

\subsubsection{Measures}

The TIMSS procedures have students first take a 90-minute test followed by a contextual questionnaire that captures different indices in connection to attitudes, beliefs and learning environment related to mathematics. The TIMSS provides an incomplete block design for the mathematics test (and science), while all students receive the same items for the contextual questionnaire (Mullis \& Martin, 2013).

Mathematics and science teachers also receive a block of questions related to the various features of the classroom and the school environment. In the analyses, only mathematics teachers' data were used and deaggregated to the student level. Please see Table 11.2 for an overview.

\subsubsection{Analyses}

Upon preliminary descriptive analyses across the constructs in SPSS, the primary analyses were performed in Mplus, version 8.4 (Muthén \& Muthén, 1998-2017). All missing data were handled using the FIML option. Following the pragmatics of a person-centred approach, the analyses were performed using latent profile analyses (LPA), which allows for the use of continuous indicators aligned with the nature of the constructs used. The LPA works by producing solutions with maximally different groups. Within each tested solution, it will assign individuals (i.e., students) who are similar across the examined indicators (i.e., student sense of school belonging, students like learning mathematics, student confidence in mathematics and students' value of mathematics) in one group. The individuals who are less similar to each other across the examined indicators will be assigned to different groups. The final outcome leads to homogeneous, but mutually exclusive, latent groups within a larger heterogeneous population, where each student is assigned to a single group. Each group represents a unique self-belief profile. Neither group composition nor the number of groups is known in advance (Geiser, 2013).

Because the profile analyses included two distinctive populations (i.e., Norway and Sweden), it was essential to investigate whether these samples could be treated as one or if the analyses were necessary for each country separately. In doing so, we were guided by the principles of the multiple-group analyses of similarity in latent profiles solutions proposed by Morin et al. (2016). In the first step, configural 
Table 11.2 Constructs used in the study

\begin{tabular}{|c|c|c|c|}
\hline \multirow[b]{2}{*}{ Construct } & \multirow[b]{2}{*}{ Description } & \multicolumn{2}{|c|}{$\begin{array}{l}\text { Mean (Standard Error) and } \\
\text { missing rate }(\%)^{\mathrm{a}}\end{array}$} \\
\hline & & Norway & Sweden \\
\hline & \multicolumn{3}{|l|}{ Achievement data } \\
\hline \multirow{2}{*}{$\begin{array}{l}\text { Student } \\
\text { achievement in } \\
\text { mathematics }\end{array}$} & First plausible value was used & $487(2.0) ; 0 \%$ & $501(2.8) ; 0 \%$ \\
\hline & \multicolumn{3}{|l|}{ Student background data } \\
\hline \multirow[t]{2}{*}{$\begin{array}{l}\text { Home educational } \\
\text { resources }\end{array}$} & $\begin{array}{l}\text { A composite score comprised of the } \\
\text { number of books at home, the highest } \\
\text { level of education of either parent and } \\
\text { number of home study supports }\end{array}$ & $\begin{array}{l}11.4(0.02) \\
1.3 \%\end{array}$ & $\begin{array}{l}11.2(0.02) \\
1.5 \%\end{array}$ \\
\hline & \multicolumn{3}{|c|}{ Students' self-belief and school environment constructs } \\
\hline $\begin{array}{l}\text { Students sense of } \\
\text { school belonging }\end{array}$ & $\begin{array}{l}\text { A seven-item composite score.Example } \\
\text { items: 'I feel safe when I am at school' }\end{array}$ & $\begin{array}{l}10.7(0.05) \\
0.2 \%\end{array}$ & $\begin{array}{l}9.7(0.06) \\
0.2 \%\end{array}$ \\
\hline $\begin{array}{l}\text { Students like } \\
\text { learning } \\
\text { mathematics }\end{array}$ & $\begin{array}{l}\text { A nine-item composite score.Example } \\
\text { items: 'I enjoy learning mathematics' }\end{array}$ & $9.7(0.05) 0.3 \%$ & $9.6(0.06) 0 \%$ \\
\hline $\begin{array}{l}\text { Students confident } \\
\text { in mathematics }\end{array}$ & $\begin{array}{l}\text { A nine-item composite score.Example } \\
\text { items: 'I learn things quickly in } \\
\text { mathematics' }\end{array}$ & $\begin{array}{l}11.0(0.07) \\
0.4 \%\end{array}$ & $\begin{array}{l}10.5(0.08) \\
0.4 \%\end{array}$ \\
\hline $\begin{array}{l}\text { Students value } \\
\text { mathematics }\end{array}$ & $\begin{array}{l}\text { A nine-item composite score.Example } \\
\text { items: 'I think learning mathematics will } \\
\text { help me in my daily life' }\end{array}$ & $10.3(0.06) 1 \%$ & $\begin{array}{l}9.4(0.05) \\
0.4 \%\end{array}$ \\
\hline Student bullying & $\begin{array}{l}\text { A nine-item composite score.Example } \\
\text { behaviour 'spread lies about me' }\end{array}$ & $\begin{array}{l}10.9(0.05) \\
0.2 \%\end{array}$ & $\begin{array}{l}10.4(0.05) \\
0.1 \%\end{array}$ \\
\hline \multirow[t]{2}{*}{$\begin{array}{l}\text { Engaging teaching } \\
\text { in math lesson }\end{array}$} & $\begin{array}{l}\text { A 10-item composite score. Example } \\
\text { items: 'My teacher is easy to understand' }\end{array}$ & $\begin{array}{l}10.0(0.05) \\
0.4 \%\end{array}$ & $9.6(0.05) 0 \%$ \\
\hline & \multicolumn{3}{|l|}{ School environment constructs (teachers) } \\
\hline $\begin{array}{l}\text { School emphasis } \\
\text { on academic } \\
\text { success }\end{array}$ & $\begin{array}{l}\text { A 14-item composite score. Example of } \\
\text { an aspect: 'Teachers' expectations for } \\
\text { student achievement' }\end{array}$ & $\begin{array}{l}10.1(0.10) \\
9.6 \%\end{array}$ & $\begin{array}{l}9.6(0.11) \\
2.9 \%\end{array}$ \\
\hline $\begin{array}{l}\text { Safe and orderly } \\
\text { schools }\end{array}$ & $\begin{array}{l}\text { An eight-item composite score.Example } \\
\text { items: 'I feel safe at this school' }\end{array}$ & $\begin{array}{l}11.2(0.12) \\
9.6 \%\end{array}$ & $\begin{array}{l}9.7(0.13) \\
2.9 \%\end{array}$ \\
\hline $\begin{array}{l}\text { School conditions } \\
\text { and resources }\end{array}$ & $\begin{array}{l}\text { A seven-item composite score. Example } \\
\text { items: 'Teachers do not have adequate } \\
\text { workspace' }\end{array}$ & $\begin{array}{l}10.3(0.11) \\
9.6 \%\end{array}$ & $\begin{array}{l}9.6(0.11) \\
2.9 \%\end{array}$ \\
\hline $\begin{array}{l}\text { Challenges facing } \\
\text { teachers }\end{array}$ & $\begin{array}{l}\text { An eight-item composite score. Example } \\
\text { items: 'There are too many students in the } \\
\text { classes' }\end{array}$ & $9.4(0.15) 9.6 \%$ & $\begin{array}{l}9.7(0.12) \\
2.4 \%\end{array}$ \\
\hline $\begin{array}{l}\text { Teaching limited } \\
\text { by student needs }\end{array}$ & $\begin{array}{l}\text { A six-item composite score. Example of } \\
\text { the need: 'Disruptive students' }\end{array}$ & $\begin{array}{l}10.6(0.12) \\
12.1 \%\end{array}$ & $\begin{array}{l}10.5(0.14) \\
6.3 \%\end{array}$ \\
\hline
\end{tabular}

${ }^{a}$ Achievement and student background data refer to full national samples because these were used to construct the final sample used for the analyses 
similarity of the profiles was validated, that is, whether the same number of latent profiles when using the same overarching model can be identified in both countries. The assumption was tested through a series of latent profile solutions that were estimated separately for Norway and Sweden by using the same set of profile indicators. In the next step, the structural similarity of the profiles was tested. This step determines whether the profiles for both countries are similar and represent a basis to explore other types of similarities or possible differences. The third step tests the dispersion similarity (i.e., if the within-profile variability of the indicators is similar across countries), followed by the distributional similarity of the profiles (i.e., if the relative size of the profiles differs or not across the nations). The final stages focused on explanatory similarity, allowing us to observe the profiles not just from the perspective of resilient and nonresilient groups in both countries, but also to investigate the school/classroom features surrounding each. All models were estimated using 5000 random start values sets with 100 iterations and the 200 best solutions retained for the final stage of optimisation.

\subsection{Results}

The results section is divided into three major components. First, we discuss the basis for establishing the joint self-belief profiles, which is followed by the saturation of resilient and nonresilient student groups. Finally, we observe the different aspects of the school environment in connection to the established self-belief profiles and how these relate to the four initial student categories.

\subsubsection{Students'Self-Belief Profiles}

In identifying the number of profiles, we examined solutions with up to seven profiles separately for Norway and Sweden. Please see the fit indices in Table 11.3. The statistical adequacy and interpretability of the solution guided our final choice for an optimal profile solution.

In the case of Norway, with the addition of the profiles, most indices continued decreasing, except for the BLRT, which remained unchanged across the inspected models. The LMR values supported five profiles, but after inspecting the neighbouring four- and the five-profile solutions, the former was accepted. The four-profile solution provided a more meaningful interpretation in relation to both the data and previous research (e.g., Kalender, 2015). Entropy was also satisfactory. In the Swedish sample, both the fit indices (AIC, BIC, SABIC, LMR) and the model interpretability supported a four-profile solution. Again, entropy was satisfactory.

A multiple-group model for the four-profile solution was then simultaneously estimated for both country samples to test for a cross-national similarity. We first tested for the configural and then the structural similarity. Both the models were 


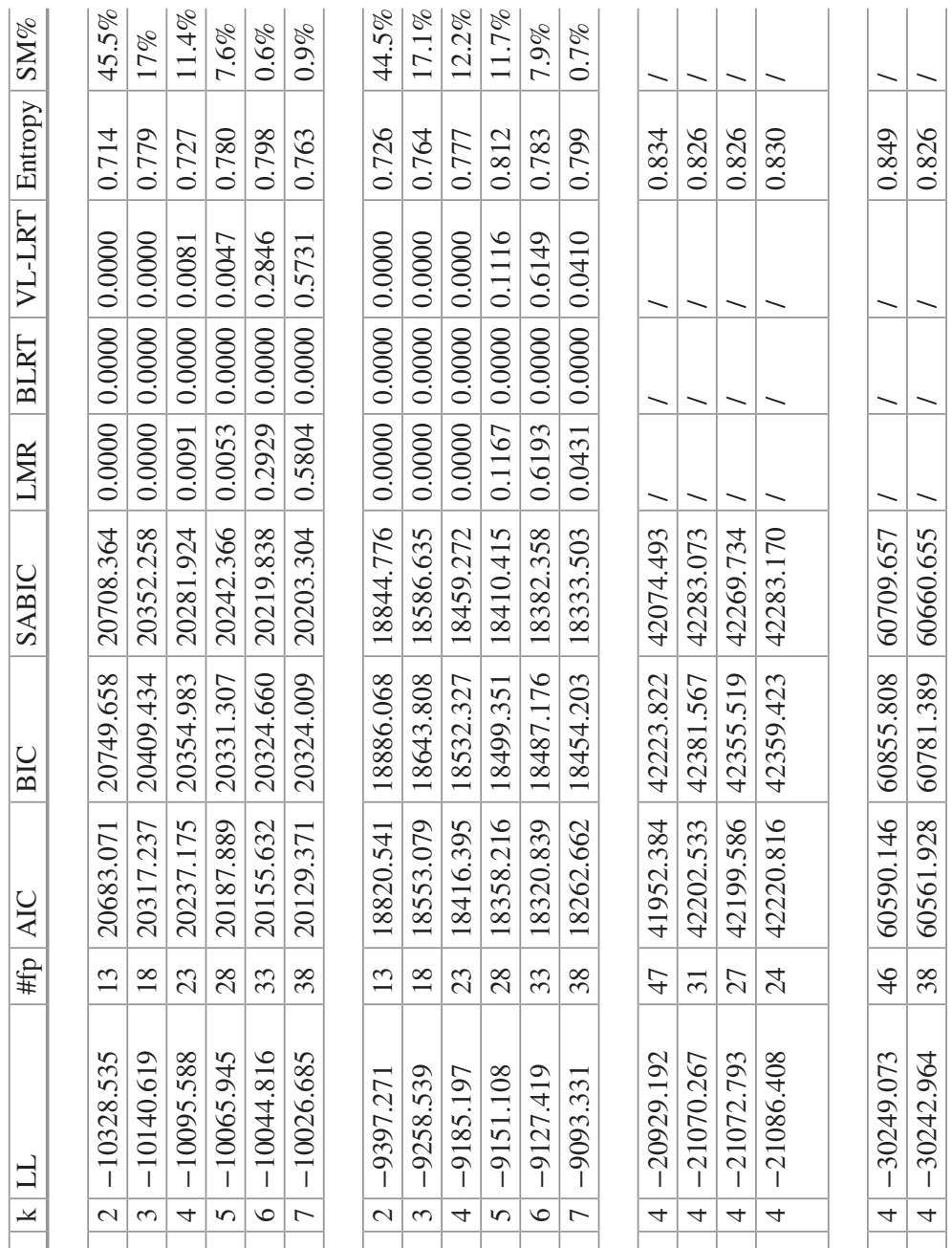

궁

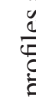

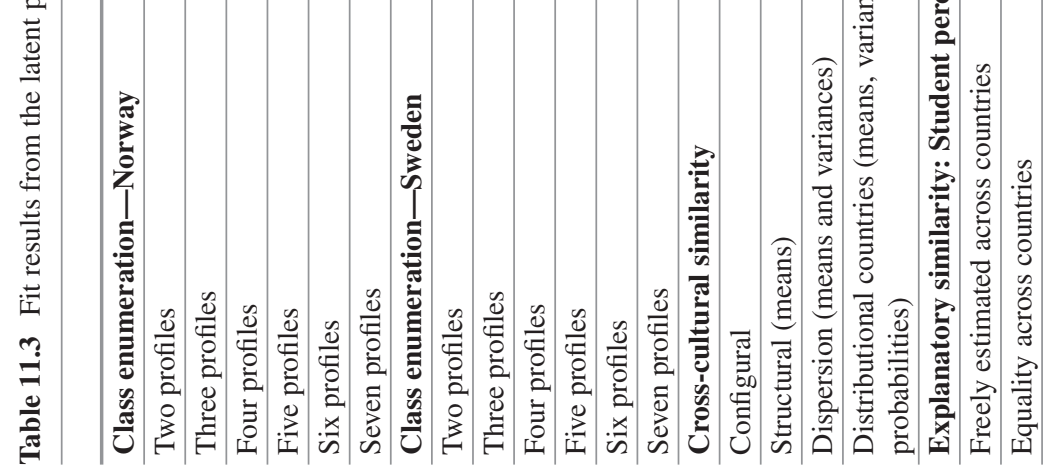


11 Resilient and Nonresilient Students in Sweden and Norway-Investigating...

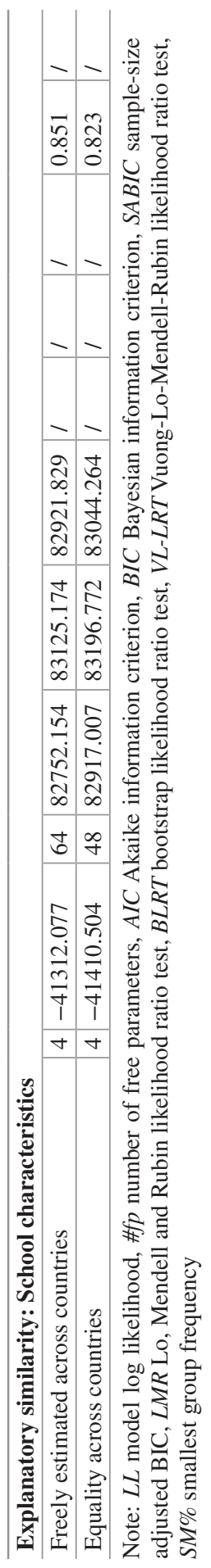


confirmed. Please see Table 11.3 for more details. The next model, testing the dispersion similarity, showed somewhat lower values for the AIC, BIC and SABIC compared with the structural similarity model. These results support the dispersion similarity; that is, the within-profile variability of the indicators is similar across Norway and Sweden. The four self-belief profiles from the dispersion similarity model are shown in Fig. 11.1. We discuss each in connection to students' sense of school belonging, students liking to learn mathematics, students being confident in mathematics and students' valuing of mathematics.

Among the profiles, the largest share of the students (38\%) do not seem to enjoy learning mathematics, find it boring or the topic to be of little interest. At the same time, the students perceive themselves as confident when it comes to mathematics as a subject. In their view, they are not lagging behind their peers and have experienced praise from their mathematics teacher. At the same time, these students do value mathematics and see it as a tool that can contribute to their success later in life. Across the dimensions, their sense of belonging to school, teachers and peers seems to be the most distinctive feature. We labelled this group as the nonadmirers because compared with the other profiles, these students do not seem to enjoy learning mathematics but still to some extent see the value of mathematics, are somewhat confident and report a high sense of school belonging.

The second-largest group (36\%) is labelled confident. Across the dimensions that entered our analyses, students' confidence concerning mathematics is their strongest characteristic. The confidence is related to their perception of doing well in mathematics or mastering difficult tasks, along with the absence of negative emotions in relation to mathematics. Almost equally strongly students report on their feeling of belonging to the school and valuing mathematics concerning their later

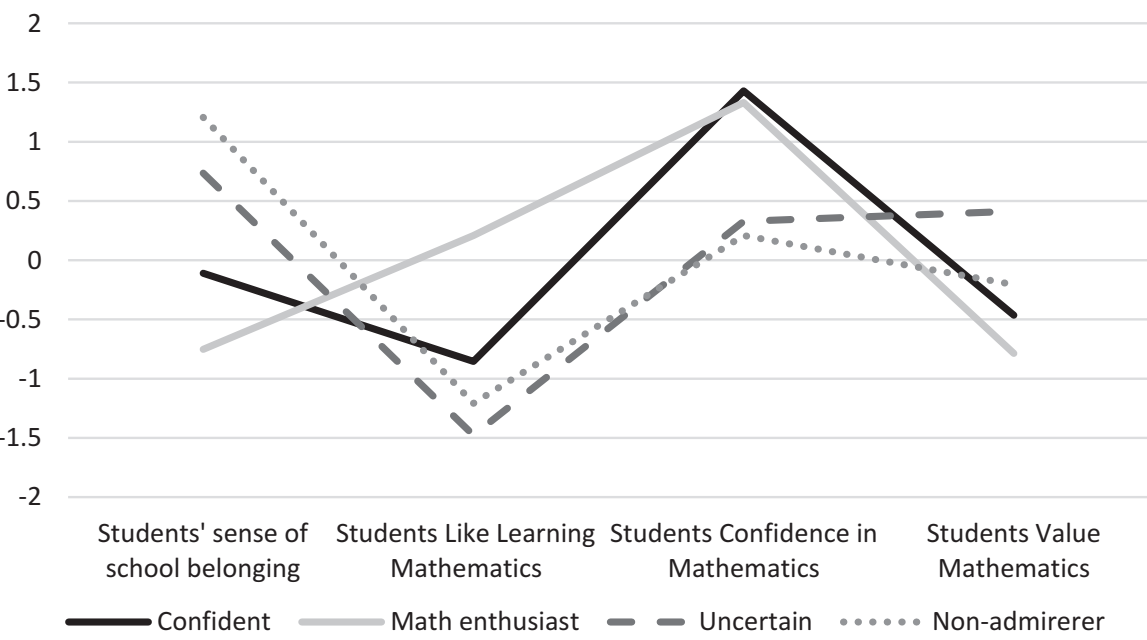

Fig. 11.1 Characteristics of the four identified self-belief profiles. (Note: The results were standardised to a mean of 0 and a standard deviation of 1 for visualisation purposes) 
life choices or daily lives. These students enjoy learning content in mathematics, yet the subject does not necessarily represent their favourite domain of interest.

The next student profile, labelled math enthusiasts, comprise $15 \%$ of all students in our sample. Across all the dimensions, these students score the highest. These include their perception of belonging to the school environment they are part of, highly regarding mathematics as a domain that will aid them in their daily life, being successful in other school subjects or later being successful in obtaining a job they aspire. These students very much like and enjoy learning content related to mathematics. Mathematics is one of their favourite subject domains. Finally, compared with the other profiles, they perceive themselves as highly confident in relation to different aspects of dealing with the content of mathematics.

The last profile gathers students that, compared with others, enjoy or like learning mathematics the least. Also, these students are the least confident when grappling with the mathematical content. To an extent, they value mathematics and see it as useful for their future or success in other domains. Across the observed dimensions, they are most favourable in relation to how they perceive their sense of school belonging. We have labelled this group as the uncertain (11\%).

\subsubsection{Resilient and Nonresilient Students and Their Characteristics}

The following steps in the analyses have allowed us to test the similarity in the size of the profiles across Sweden and Norway (the distributional similarity). Compared with previous results on dispersion, where we tested whether the within-profile variability of the indicators is similar across countries, the values across the observed criteria have increased (i.e., AIC, BIC, SABIC), suggesting that the sizes of the profiles somewhat differ across both Sweden and Norway. In both countries, nonadmirers and confident profiles are dominant. Both mount to nearly $37 \%$ in Norway and $41 \%$ for the former and $34 \%$ for the latter in Sweden. In absolute numbers, the nonadmirers have a greater share in the overall population compared with Norway, whereas for the confident profile, this share is about the same. Compared with Sweden, in Norway, we find more students in the math enthusiasts profile (17\% and $12 \%$, respectively). Finally, in both countries, the saturation within the uncertain profile is the least but somewhat higher for Sweden (9.5\% and $13 \%$ respectively).

To further shed light on the presence of each of the four profiles, we observe the profiles concerning the categories that present the building blocks of our sample, that is, the academically resilient category, failing under risk students, low-achieving category and the nonrisk achievers (Table 11.4). Significant differences were registered regarding the occurrence of the student categories in relation to the examined profiles $\left(\chi^{2}(21)=826.634, \mathrm{p}<0.001\right)$. In both countries, the math enthusiast and confident profiles have a higher occurrence among the nonrisk achievers. Both of the profiles are viewed as optimal because both in different ways suggest positive 
Table 11.4 Students' self-belief profiles and categories

\begin{tabular}{|c|c|c|c|c|c|}
\hline \multirow[b]{2}{*}{ Sample categories } & & \multicolumn{4}{|c|}{ Student profiles } \\
\hline & & Confident & Math enthusiast & Uncertain & Nonadmirer \\
\hline \multicolumn{6}{|l|}{ Norway } \\
\hline \multirow[t]{2}{*}{ Academically resilient group } & $\%$ & $55.0 \%$ & $18.3 \%$ & $5.5 \%$ & $21.1 \%$ \\
\hline & St. res. & 3.3 & 0.9 & -1.7 & -2.9 \\
\hline \multirow[t]{2}{*}{ Failing under risk students } & $\%$ & $27.4 \%$ & $4.3 \%$ & $17.3 \%$ & $51.0 \%$ \\
\hline & St. res. & -3.1 & -5.9 & 4.1 & 4.5 \\
\hline \multirow[t]{2}{*}{ Low-achieving group } & $\%$ & $33.8 \%$ & $2.2 \%$ & $16.2 \%$ & $47.8 \%$ \\
\hline & St. res. & -0.4 & -3.8 & 1.8 & 1.9 \\
\hline \multirow[t]{2}{*}{ Nonrisk achievers } & $\%$ & $48.0 \%$ & $33.1 \%$ & $1.7 \%$ & $17.1 \%$ \\
\hline & St. res. & 4.6 & 10.8 & -6.4 & -7.8 \\
\hline \multicolumn{6}{|l|}{ Sweden } \\
\hline \multirow[t]{2}{*}{ Academically resilient group } & $\%$ & $47.9 \%$ & $11.7 \%$ & $6.4 \%$ & $34.0 \%$ \\
\hline & St. res. & 1.9 & -0.8 & -1.3 & -0.6 \\
\hline \multirow[t]{2}{*}{ Failing under risk students } & $\%$ & $13.1 \%$ & $2.3 \%$ & $22.7 \%$ & $61.8 \%$ \\
\hline & St. res. & -8.6 & -7.4 & 8.0 & 8.7 \\
\hline \multirow[t]{2}{*}{ Low-achieving group } & $\%$ & $16.7 \%$ & $1.3 \%$ & $23.1 \%$ & $59.0 \%$ \\
\hline & St. res. & -2.9 & -3.1 & 3.2 & 3.0 \\
\hline \multirow[t]{2}{*}{ Nonrisk achievers } & $\%$ & $53.6 \%$ & $24.6 \%$ & $0.9 \%$ & $20.9 \%$ \\
\hline & St. res. & 6.2 & 5.4 & -6.5 & -5.9 \\
\hline
\end{tabular}

Note: Frequency is provided for within the category. The standard residual with values over 1.9 indicate a statistically significant difference

attitudes and emotions towards a variety of aspects in connection to mathematics learning or valuing one's own competence. Although the pattern is stronger for the confident profile in Sweden, in Norway, this is the case for the math enthusiasts (see Table 11.4, standardised residual values). As expected, the failing under risk category of students is underrepresented in both of these profiles, but again, the pattern is stronger than in Sweden. As to the low-achieving category, we find significantly fewer students in Sweden belonging to these two profiles. For Norway, the trend is only noticeable for the confident profile.

Overall, the failing under risk and low-achieving categories are overrepresented in the uncertain and the nonadmirer profiles. Both profiles are linked to negative perceptions of mathematics as a subject. Students within the latter group do exhibit some confidence in their competence and, to an extent, may value mathematics. With some exceptions for Norway, the pattern is very strong for both these groups in Sweden.

As for the academically resilient students, in Norway, they are underrepresented in the nonadmirer profile and overrepresented in the confident profile. The latter is similar to the results for Sweden although the pattern is somewhat weaker. Interestingly, when observing the resilient students, no distinctive pattern is found for the math enthusiast profile in either of the countries. Although these students may be found among those that profoundly enjoy and like learning the content of mathematics, value the subject and are confident when grappling with the 
mathematical content, they are rather overrepresented in the other profile that we also consider to be optimal. At the same time, the mere fact we find significantly more resilient students within the confident profile can also be seen as a distinctive characteristic of resilience itself. Resilient students succeed despite an adverse background or when met with a set of unfavourable factors. To do so, they need to believe in themselves and the abilities they possess. For the confident profile, this is the very thing that sets them apart from the other profiles we found.

\subsubsection{The School and the Classroom Environment}

An essential aspect of our investigation was also related to examining classroom and school environment features distinctive to the profiles and how the profile membership is differentially associated with each of these. To achieve this aim, we tested an explanatory similarity model across the samples, starting with student perceptions of student bullying and engagement of the teaching in the math lesson. We first conducted a model that allows within-profile levels of both these aspects to be freely estimated across the samples and then a model in which these levels were constrained to be equal across the samples. The latter model resulted in lower values for AIC, BIC and SABIC (Table 11.3), thus supporting the explanatory similarity. Systemic tests of mean level differences across the pairs of profiles (Table 11.5) revealed significant differences between all the profiles regarding students' perceptions of engaging teaching in mathematics. The math enthusiast group, which is saturated by resilient and nonrisk achievers, holds the most positive perceptions of the instruction they are exposed to. In their view, the teachers are clear with the instruction, engaging and provide them with feedback that is attuned to their needs.

Table 11.5 Students' self-belief profiles and classroom and school environment

\begin{tabular}{|c|c|c|c|c|c|}
\hline \multirow[b]{2}{*}{ Sample categories } & \multicolumn{4}{|c|}{ Student profiles } & \multirow[b]{2}{*}{ Tests of significance } \\
\hline & $\begin{array}{l}\text { Math } \\
\text { enthusiast }\end{array}$ & Confident & Uncertain & Nonadmirer & \\
\hline Student bullying & 11.160 & 10.094 & 9.881 & 11.124 & $\begin{array}{l}1>2 ; 1>3 ; 1=4 \\
2=3 ; 2<4 ; 3<4\end{array}$ \\
\hline $\begin{array}{l}\text { Engaging teaching in } \\
\text { math lesson }\end{array}$ & 11.402 & 9.522 & 7.976 & 9.899 & $\begin{array}{l}1>2 ; 1>3 ; 1>4 \\
2>3 ; 2<4 ; 3<4\end{array}$ \\
\hline $\begin{array}{l}\text { School emphasis on } \\
\text { academic success }\end{array}$ & 10.558 & 9.180 & 9.313 & 10.506 & $\begin{array}{l}1>2 ; 1>3 ; 1=4 \\
2=3 ; 2<4 ; 3<4\end{array}$ \\
\hline $\begin{array}{l}\text { Safe and orderly } \\
\text { schools }\end{array}$ & 11.072 & 8.969 & 9.961 & 11.566 & $\begin{array}{l}1>2 ; 1=3 ; 1=4 \\
2=3 ; 2<4 ; 3<4\end{array}$ \\
\hline $\begin{array}{l}\text { School conditions and } \\
\text { resources }\end{array}$ & 10.317 & 9.184 & 9.959 & 10.584 & $\begin{array}{l}1=2 ; 1=3 ; 1=4 \\
2<3 ; 2<4 ; 3=4\end{array}$ \\
\hline $\begin{array}{l}\text { Challenges facing } \\
\text { teachers }\end{array}$ & 9.248 & 9.718 & 9.513 & 9.341 & $\begin{array}{l}1<2 ; 1=3 ; 1=4 \\
2=3 ; 2=4 ; 3=4\end{array}$ \\
\hline
\end{tabular}

Note: See Appendix for details on significance tests 
The least positive perceptions are typical of the uncertain group. For them, the instruction is difficult to follow, uninteresting and without clear evidence to show them if they have mastered the subject. If we take into account that the uncertain profile is very much saturated by failing under risk students, this finding creates an opportunity to observe the further particular needs this group may have in relation to the instruction they may or may not be receiving. The mean level differences across the profiles have also been captured concerning students' perceptions of bullying experienced. However, neither of these values falls under 9.3, which is a critical score that shifts a student from the category 'almost never' to 'about monthly' when observing this scale within the existing TIMSS framework (Mullis \& Martin, 2013; see also Appendix).

Finally, we tested whether the relations between the student profiles and particular distal features - school emphasis on academic success, safe and orderly schools, school conditions and resources and the challenges facing teachers and teaching limited by students' needs are replicated across the profiles. The assumption was not confirmed (the AIC, BIC and SABIC values are lower for equality across the countries model, Table 11.3). Furthermore, the mean level test differences across the pairs of profiles (Table 11.5) reveal a distinctive pattern.

According to teacher perceptions, all students are placed in school environments in which their math teachers do face some challenges related to the organisation of their own teaching, or minor problems are reported as to the school's conditions and resources. Yet the challenges seem to be somewhat more significant for students belonging to the confident profile. Given the fact that both resilient and nonrisk achievers saturate the profile, it is essential to understand how these students manage to compensate for the possible barriers related to these challenges and the extent their self-belief capacities aid them in the process. The finding is even more important in light of the result that these students are also in school environments in which the school's emphasis on academic success is perceived to be at a medium level. Similarly, students within the uncertain profile face the same challenge. Although the profile itself is the least optimal among all the profiles, the uncertain profile is also very much saturated by students in the category failing under risk and lowachieving students. Thus, the finding, together with students' perception of lessthan-engaging teaching in mathematics, may imply some of the students in this profile could be facing adverse conditions both at school and home.

Although the nonadmirer profile is also saturated by students in the categories failing under risk and low-achieving, the school's emphasis on academic success is ranked very high, and students have perceived the teaching as engaging. This could be viewed as a compensatory mechanism that aids the students who fail in maintaining certain levels of confidence and valuing mathematics, which is distinctive of the profile. Despite some mean differences across the four profiles for the safe and orderly school as reported by the teachers, overall, all students may be tied to at least safe and orderly category. In the case of math enthusiasts and nonadmirer profiles, the teachers report very safe and orderly school milieus. 


\subsection{Discussion}

Ensuring the success of every child in an equal way is an essential aspect of the agenda for many education providers across the world (Doll, 2013; Pianta \& Walsh, 1998). In particular, this includes the Nordic countries, which are often viewed as among the top leading countries with such an agenda (Blossing et al., 2014), despite the argument regarding how Sweden has somewhat lost its position among these countries (Blossing \& Söderström, 2014; Lundahl, 2016; Skolverket, 2013). At the same time, a significant strand of researchers has been trying to capture and examine the mechanisms that could explain the achievement gap between low- and highSES students (e.g. Broer et al., 2019; OECD, 2019; Wiberg, 2019) and how these may relate different education reforms (e.g., Lundahl, 2016). Conversely, others focus on the adverse background students may be facing, here mapping out both the student and school characteristics that could support students' academic success despite the adversities they face (Doll, 2013). Against this background, we conducted a study aiming to examine the distinct differences between resilient and nonresilient student groups (Lee \& Smith, 1999; OECD, 2018; Sattler \& Gershoff, 2019) in connection to their self-beliefs related to mathematics (i.e., confidence, interest and value) and sense of school belonging. Furthermore, we investigated the school and classroom environment of students with distinct self-belief patterns and how these relate to students initially categorised as resilient or not.

We expected the optimal self-belief profiles to attract both resilient students (i.e., high-achieving students with low SES) and nonrisk achievers (i.e., high-achieving students with high SES) (Erberber et al., 2015; Kalender, 2015; Martin \& Marsh, 2006; Sandoval-Hernández \& Białowolski, 2016; Wayman, 2002). We also expected low-achieving students, irrespective of their SES, to be more frequently found in the less-optimal profiles. The assumption was partially confirmed. Both the math enthusiast and confident profiles gathered substantially more nonrisk achievers. At the same time, in both Norway and Sweden, a large fraction of the resilient students were found in the confident profile but far less were found in the math enthusiast profile. The fact that we do capture more resilient students in a profile associated with high levels of confidence in mathematics resonates with the findings in existing studies (e.g., Martin \& Marsh, 2006; Sandoval-Hernández \& Białowolski, 2016; Wayman, 2002). However, the aspect of liking mathematics and genuinely enjoying grappling with the mathematical content, which was more a characteristic of the math enthusiast profile, was strongly linked with the nonrisk achievers. For students saturating each of the two profiles, the higher proportion of resilient students being found in the confident profile may be expected. If we regard confidence as one of the major correlates of resilience, its higher levels could be viewed as an aid or even a compensatory mechanism students develop in battling adverse circumstances as they strive to succeed. Enjoyment in an actual activity may become secondary, but it is essential for students' perseverance.

Both the nonadmirer and the uncertain profiles were overrepresented by the lowachieving and failing under risk categories. At the same time, students in the 
nonadmirer profile exhibit some confidence in their competence and, to an extent, value mathematics, even though they may find it uninteresting. Thus, the finding contradicts the expected pattern reported in previous studies (e.g., Kalender, 2015; Sandoval-Hernández \& Białowolski, 2016), indicating further investigation is necessary for contrasting the resilient and nonresilient student categories. This also underlines the importance of taking into account the heterogeneity of the student population and points to the importance of the different criteria used in distinguishing resilient from the nonresilient students (i.e., low-threshold and high-threshold resilience; Sattler \& Gershoff, 2019) and how their combination adds to the complexity in assessing the needs of diverse students.

The other part of our investigation focused on the constituents of the classroom and school environment. Based on previous research, we expected optimal profiles (i.e., math enthusiasts and the confident profile) to be found within environments with a strong school emphasis on academic success (Erberber et al., 2015; Hoy et al., 2006) and a safe and orderly climate (Wang \& Degol, 2016) with less frequently reported experiences of bullying (Erberber et al., 2015). Again, these assumptions were only partially confirmed. Across profiles, a safe and orderly climate and almost no experience with bullying was reported by both teachers and students. Although this contradicts some previous results (Erberber et al., 2015; Wang \& Degol, 2016), the finding is in line with the results for Sweden and Norway on the lower frequency of reported bullying overall and safe school environments (Jensen et al., 2019; OECD, 2018). However, the findings in connection to school emphasis on academic success and school conditions and resources point to some distinctive patterns across the profiles, shedding light on the very idea of equality of opportunities and outcome, as proposed by Espinoza (2007). Across the investigated profiles, students within the confident profile seem to be affected the most by the reported challenges related to the organisation of teaching or minor difficulties with the school conditions and resources. The finding is coupled with the perception of a school environment not strongly focusing on academic success. Importantly, resilient and nonrisk achiever categories saturate the confident profile, and both are strong achievers. Students within the uncertain profile face the same challenges, but compared with the previous profile, they report less-engaging teaching. The uncertain profile is also very much saturated by students in the category failing under risk and low-achieving students. Thus, although the school environment is the same for both, within their immediate surrounding - the classroom-students from the confident profile do experience some compensatory mechanism through instruction they perceive as engaging (Ungar et al., 2019) and are supported by their own strong performance. Regarding the uncertain profile, the adverse characteristics pertain both in the school and classroom, and for many, these extend to the home environment (i.e., low SES). If we take into account that education in the Nordic welfare system has been regarded as a crucial instrument for social justice and security, the perceived differences for the two described profiles contradict this very idea. Although both are examples of inequality of opportunity, the uncertain profile is also under risk of inequality related to the output when considering the profile's 
saturation with failing and low SES students, as well as availability in the school and classroom resources (Espinoza, 2007).

As reported, the nonadmirers profile is also overrepresented by students in the categories failing under risk and low achieving. However, their teachers reported strong school emphasis on academic success, whereas the students themselves perceived the teaching as engaging. Both aspects could be observed as compensatory mechanisms that aid students who fail in maintaining certain levels of confidence and valuing mathematics, which is distinctive of the profile. Thus, in the context of support that schools can provide to students (Hoy et al., 2006; Kyriakides et al., 2010; Maxwell et al., 2017), we postulate that interventions addressing these two aspects could be a fruitful ground in ensuring more equal chances across different at-risk groups, supporting both their outcomes and engagement (Martin et al., 2013; O'Brennan \& Furlong, 2010; Wang \& Degol, 2016).

Finally, some distinctive differences between Norway and Sweden were found in the frequency of each student category, despite the existence of the same four profiles in both countries. In the context of the necessity to primarily support students with adverse social background (i.e., resilient and failing under risk categories), in Norway, these students are represented more frequently in the optimal self-beliefs profiles. Given the latest trends in the Swedish education system (e.g., Lundahl, 2016) and a higher degree of SES variation within compulsory schools in Norway (OECD, 2019), this warrants further investigation into school characteristics and existing practices, going beyond school SES (Lee \& Smith, 1999) and again controlling for country differences (Sandoval-Hernández \& Białowolski, 2016).

\subsubsection{Limitation and Future Research}

One important limitation of our work stems from the nature of the data used, that is, cross-sectional data. Although the data allow for diverse analyses such as latent profiling, it is not possible to determine if the students remain in the same profiles across time. Besides the opportunity to follow student trajectories, latent transition analyses would allow for an even more in-depth understanding of the interplay between the individual, classroom and school-level characteristics in the context of these phenomena. A study of this nature would also aid in tracing the possible effects of targeted intervention towards both resilient and nonresilient student categories. In the context of our results, one such example would be following whether students from the uncertain profile may shift to the nonadmirers after being supported by an intervention at the school and classroom level or whether the same transition may occur between the confident and math enthusiast profile. Second, although the TIMSS data have allowed us to run models for Norway and Sweden simultaneously, we were limited by the constructs provided in the study and its overall organisation. Thus, it can be argued that more or other school and classroom characteristics may have been added to this investigation, both at the teacher and the student level. Although this may hold, our current choice from the variable poll was 
anchored and supported by previous research. Finally, aligned with the personcentred approach, students and their characteristics were the focus of this investigation, irrespective of the actual schools they may have been enrolled in. The former was the reason for merging student and teacher data, that is, deaggregating them to the student level. Although the process can lead to a type II error, thus underestimating some patterns in the data, we could also observe evidence where the student and teacher data were corroborating with each other. An example could be found in the findings on the perception of a safe and orderly climate.

\subsection{Concluding Remarks}

Apart from the optimal outcomes concerning achievement, students are also expected to develop an optimal set of self-beliefs that will aid them in the process of education and allow them to persevere once their interests are further profiled. Such expectations are set for all students, irrespective of their social backgrounds. Following Erberber et al. (2015), who caution proposing universal recipes in comparative research, a more focused country choice approach was adopted in the current study. The method was coupled with combining low- and high-threshold criteria when distinguishing between resilient and nonresilient student categories (Sattler \& Gershoff, 2019), allowing us to identify particular patterns about the classroom and school characteristics after accounting for students' self-beliefs. The method has also aided in moving beyond the resilient and nonresilient divide, capturing finegrained differences in the student population, respective also to the cross-country differences. In addition, we were able to identify particular student profiles that might be more prone to risk after accounting not merely for students' SES, but also for the individual strengths and hindrances in the classroom, along with the school setting. In the context of the equality-inequality paradigm (Espinoza, 2007), recognition of such student subgroups strengthen the possibility to reduce the gap in battling different aspects of inequality across social groups.

Also, our results speak both in favour and against the very idea of the Nordic model. Although we have been able to distinguish the same student groups across Sweden and Norway, confirming some commonalities across both countries, their distribution within each differs. Observing more students with an adverse social background in the optimal self-beliefs profiles was not replicated in Sweden the same way it was in Norway. This result speaks of some diverse pathways although both countries are considered representative of the Nordic model. Having in mind the latest developmental trends in the Swedish education system and student composition across the schools in Norway creates space for a more focused investigation into the existence of particular school practices and mechanisms catering to diverse students within the education system of both countries. Their existence could provide clearer evidence of the possible dissolution of the Nordic model. 


\section{Appendices}

\section{Appendix 1: List of Constructs with Items and Scale Range}

\begin{tabular}{|c|c|c|}
\hline Construct & Construct items & Range \\
\hline \multicolumn{3}{|c|}{ Student questionnaire } \\
\hline \multirow{3}{*}{$\begin{array}{l}\text { Home educational } \\
\text { resources }\end{array}$} & (1) Number of books in the home & \multirow{3}{*}{$\begin{array}{l}\text { Scale ranging from Many Resources } \\
\text { (score of at least 12.4) to Few Resources } \\
\text { (score no higher than 8.3) }\end{array}$} \\
\hline & $\begin{array}{l}\text { (2) Highest level of education of } \\
\text { either parent }\end{array}$ & \\
\hline & $\begin{array}{l}\text { (3) Number of home study } \\
\text { supports }\end{array}$ & \\
\hline \multirow{7}{*}{$\begin{array}{l}\text { Sense of school } \\
\text { belonging scale, } \\
\text { eight grade }\end{array}$} & (1) I like being in school & \multirow{7}{*}{$\begin{array}{l}\text { Scale ranging from High Sense of } \\
\text { School Belonging (score of at least 10.3) } \\
\text { to Little Sense of School Belonging } \\
\text { (score no higher than 7.5) }\end{array}$} \\
\hline & (2) I feel safe when I am at school & \\
\hline & $\begin{array}{l}\text { (3) I feel like I belong at this } \\
\text { school }\end{array}$ & \\
\hline & $\begin{array}{l}\text { (4) I like to see my classmates at } \\
\text { school }\end{array}$ & \\
\hline & $\begin{array}{l}\text { (5) Teachers at my school are fair } \\
\text { to me }\end{array}$ & \\
\hline & (6) I am proud to go to this school & \\
\hline & (7) I learn a lot in school & \\
\hline \multirow{9}{*}{$\begin{array}{l}\text { Students like } \\
\text { learning } \\
\text { mathematics }\end{array}$} & (1) I enjoy learning mathematics & \multirow{9}{*}{$\begin{array}{l}\text { Scale ranging from Very Much Like } \\
\text { Learning Mathematics (score of at least } \\
\text { 11.4) to Do Not Like Learning } \\
\text { Mathematics (score no higher than 9.4) }\end{array}$} \\
\hline & $\begin{array}{l}\text { (2) I wish I did not have to study } \\
\text { mathematics* }\end{array}$ & \\
\hline & (3) Mathematics is boring* & \\
\hline & $\begin{array}{l}\text { (4) I learn many interesting things } \\
\text { in mathematics }\end{array}$ & \\
\hline & (5) I like mathematics & \\
\hline & $\begin{array}{l}\text { (6) I like any schoolwork that } \\
\text { involves numbers }\end{array}$ & \\
\hline & $\begin{array}{l}\text { (7) I like to solve mathematics } \\
\text { problems }\end{array}$ & \\
\hline & $\begin{array}{l}\text { (8) I look forward to mathematics } \\
\text { class }\end{array}$ & \\
\hline & $\begin{array}{l}\text { (9) Mathematics is one of my } \\
\text { favorite subjects }\end{array}$ & \\
\hline
\end{tabular}




\begin{tabular}{|c|c|c|}
\hline Construct & Construct items & Range \\
\hline \multirow[t]{9}{*}{$\begin{array}{l}\text { Students confident } \\
\text { in mathematics }\end{array}$} & $\begin{array}{l}\text { (1) I usually do well in } \\
\text { mathematics }\end{array}$ & \multirow{9}{*}{$\begin{array}{l}\text { Scale ranging from Very Confident in } \\
\text { Mathematics (score of at least } 12.1 \text { ) to } \\
\text { Not Confident in Mathematics (score no } \\
\text { higher than 9.5) }\end{array}$} \\
\hline & $\begin{array}{l}\text { (2) Mathematics is more difficult } \\
\text { for me than for many of my } \\
\text { classmates* }\end{array}$ & \\
\hline & $\begin{array}{l}\text { (3) Mathematics is not one of my } \\
\text { strengths* }\end{array}$ & \\
\hline & $\begin{array}{l}\text { (4) I learn things quickly in } \\
\text { mathematics }\end{array}$ & \\
\hline & $\begin{array}{l}\text { (5) Mathematics makes me } \\
\text { nervous* }\end{array}$ & \\
\hline & $\begin{array}{l}\text { (6) I am good at working out } \\
\text { difficult mathematics problems }\end{array}$ & \\
\hline & $\begin{array}{l}\text { (7) My teacher tells me I am good } \\
\text { at mathematics }\end{array}$ & \\
\hline & $\begin{array}{l}\text { (8) Mathematics is harder for me } \\
\text { than any other subject* }\end{array}$ & \\
\hline & $\begin{array}{l}\text { (9) Mathematics makes me } \\
\text { confused* }\end{array}$ & \\
\hline \multirow[t]{9}{*}{$\begin{array}{l}\text { Students value } \\
\text { mathematics }\end{array}$} & $\begin{array}{l}\text { (1) I think learning mathematics } \\
\text { will help me in my daily life. }\end{array}$ & \multirow{9}{*}{$\begin{array}{l}\text { Scale ranging from Strongly Value } \\
\text { Mathematics (score of at least 10.3) to } \\
\text { Do Not Value Mathematics (score no } \\
\text { higher than 7.7) }\end{array}$} \\
\hline & $\begin{array}{l}\text { (2) I need mathematics to learn } \\
\text { other school subjects }\end{array}$ & \\
\hline & $\begin{array}{l}\text { (3) I need to do well in } \\
\text { mathematics to get into the } \\
\text { university of my choice }\end{array}$ & \\
\hline & \begin{tabular}{|l|} 
(4) I need to do well in \\
mathematics to get the job I want
\end{tabular} & \\
\hline & $\begin{array}{l}\text { (5) I would like a job that } \\
\text { involves using mathematics }\end{array}$ & \\
\hline & $\begin{array}{l}\text { (6) It is important to learn about } \\
\text { mathematics to get ahead in the } \\
\text { world }\end{array}$ & \\
\hline & $\begin{array}{l}\text { (7) Learning mathematics will } \\
\text { give me more job opportunities } \\
\text { when I am an adult }\end{array}$ & \\
\hline & $\begin{array}{l}\text { (8) My parents think that it is } \\
\text { important that I do well in } \\
\text { mathematics }\end{array}$ & \\
\hline & $\begin{array}{l}\text { (9) It is important to do well in } \\
\text { mathematics }\end{array}$ & \\
\hline
\end{tabular}




\begin{tabular}{|c|c|c|}
\hline Construct & Construct items & Range \\
\hline \multicolumn{3}{|c|}{ Student questionnaire } \\
\hline \multirow[t]{9}{*}{ Student bullying } & $\begin{array}{l}\text { (1) Made fun of me or called me } \\
\text { names }\end{array}$ & \multirow{9}{*}{$\begin{array}{l}\text { Scale ranging from Almost Never (score } \\
\text { of at least 9.3) to About Weekly (score } \\
\text { no higher than 7.3) }\end{array}$} \\
\hline & $\begin{array}{l}\text { (2) Left me out of their games or } \\
\text { activities }\end{array}$ & \\
\hline & (3) Spread lies about me & \\
\hline & (4) Stole something from me & \\
\hline & $\begin{array}{l}\text { (5) Hit or hurt me (e.g. shoving, } \\
\text { hitting, kicking) }\end{array}$ & \\
\hline & $\begin{array}{l}\text { (6) Made me do things I didn't } \\
\text { want to do }\end{array}$ & \\
\hline & $\begin{array}{l}\text { (7) Shared embarrassing } \\
\text { information about me }\end{array}$ & \\
\hline & $\begin{array}{l}\text { (8) Posted embarrassing things } \\
\text { about me online }\end{array}$ & \\
\hline & (9) Threatened me & \\
\hline \multirow[t]{10}{*}{$\begin{array}{l}\text { Engaging teaching } \\
\text { in math lesson }\end{array}$} & $\begin{array}{l}\text { (1) I know what my teacher } \\
\text { expects me to do }\end{array}$ & \multirow{10}{*}{$\begin{array}{l}\text { Scale ranging from Very Engaging } \\
\text { Teaching (score of at least 10.4) to Less } \\
\text { Than Engaging Teaching (score no } \\
\text { higher than 8.2) }\end{array}$} \\
\hline & $\begin{array}{l}\text { (2) My teacher is easy to } \\
\text { understand }\end{array}$ & \\
\hline & $\begin{array}{l}\text { (3) I am interested in what my } \\
\text { teacher says }\end{array}$ & \\
\hline & $\begin{array}{l}\text { (4) My teacher gives me } \\
\text { interesting things to do }\end{array}$ & \\
\hline & $\begin{array}{l}\text { (5) My teacher has clear answers } \\
\text { to my questions }\end{array}$ & \\
\hline & $\begin{array}{l}\text { (6) My teacher is good at } \\
\text { explaining mathematics }\end{array}$ & \\
\hline & $\begin{array}{l}\text { (7) My teacher lets me show what } \\
\text { I have learned }\end{array}$ & \\
\hline & $\begin{array}{l}\text { (8) My teacher does a variety of } \\
\text { things to help us learn }\end{array}$ & \\
\hline & $\begin{array}{l}\text { (9) My teacher tells me how to do } \\
\text { better when I make a mistake }\end{array}$ & \\
\hline & $\begin{array}{l}\text { (10) My teacher listens to what I } \\
\text { have to say }\end{array}$ & \\
\hline
\end{tabular}




\begin{tabular}{|c|c|c|}
\hline Construct & Construct items & Range \\
\hline \multicolumn{3}{|c|}{ Teacher questionnaire } \\
\hline \multirow{14}{*}{$\begin{array}{l}\text { School emphasis } \\
\text { on academic } \\
\text { success }\end{array}$} & $\begin{array}{l}\text { (1) Teachers' understanding of } \\
\text { the school's curricular goals }\end{array}$ & \multirow{14}{*}{$\begin{array}{l}\text { Scale ranging from Very High Emphasis } \\
\text { (score of at least 13.4) to Medium } \\
\text { Emphasis (score no higher than 9.8) }\end{array}$} \\
\hline & $\begin{array}{l}\text { (2) Teachers' degree of success in } \\
\text { implementing the school's } \\
\text { curriculum }\end{array}$ & \\
\hline & $\begin{array}{l}\text { (3) Teachers' expectations for } \\
\text { student achievement }\end{array}$ & \\
\hline & $\begin{array}{l}\text { (4) Teachers working together to } \\
\text { improve student achievement }\end{array}$ & \\
\hline & $\begin{array}{l}\text { (5) Teachers' ability to inspire } \\
\text { students }\end{array}$ & \\
\hline & $\begin{array}{l}\text { (6) Parental involvement in } \\
\text { school activities }\end{array}$ & \\
\hline & $\begin{array}{l}\text { (7) Parental commitment to } \\
\text { ensure that students are ready to } \\
\text { learn }\end{array}$ & \\
\hline & $\begin{array}{l}\text { (8) Parental expectations for } \\
\text { student achievement }\end{array}$ & \\
\hline & $\begin{array}{l}\text { (9) Parental support for student } \\
\text { achievement }\end{array}$ & \\
\hline & $\begin{array}{l}\text { (10) Parental pressure for the } \\
\text { school to maintain high academic } \\
\text { standards }\end{array}$ & \\
\hline & $\begin{array}{l}\text { (11) Students' desire to do well in } \\
\text { school }\end{array}$ & \\
\hline & $\begin{array}{l}\text { (12) Students' ability to reach } \\
\text { school's academic goals }\end{array}$ & \\
\hline & $\begin{array}{l}\text { (13) Students' respect for } \\
\text { classmates who excel in school }\end{array}$ & \\
\hline & $\begin{array}{l}\text { (14) Collaboration between } \\
\text { school leadership and teachers to } \\
\text { plan instruction }\end{array}$ & \\
\hline \multirow[t]{8}{*}{$\begin{array}{l}\text { Safe and orderly } \\
\text { schools }\end{array}$} & $\begin{array}{l}\text { (1) This school is located in a } \\
\text { safe neighborhood }\end{array}$ & \multirow{8}{*}{$\begin{array}{l}\text { Scale ranging from Very Safe and } \\
\text { Orderly (score of at least 10.6) to Less } \\
\text { than Safe and Orderly (score no higher } \\
\text { than 7.2) }\end{array}$} \\
\hline & (2) I feel safe at this school & \\
\hline & $\begin{array}{l}\text { (3) This school's security policies } \\
\text { and practices are sufficient }\end{array}$ & \\
\hline & $\begin{array}{l}\text { (4) The students behave in an } \\
\text { orderly manner }\end{array}$ & \\
\hline & $\begin{array}{l}\text { (5) The students are respectful of } \\
\text { the teachers }\end{array}$ & \\
\hline & $\begin{array}{l}\text { (6) The students respect school } \\
\text { property }\end{array}$ & \\
\hline & $\begin{array}{l}\text { (7) This school has clear rules } \\
\text { about student conduct }\end{array}$ & \\
\hline & $\begin{array}{l}\text { (8) This school's rules are } \\
\text { enforced in a fair and consistent } \\
\text { manner }\end{array}$ & \\
\hline
\end{tabular}




\begin{tabular}{|c|c|c|}
\hline Construct & Construct items & Range \\
\hline \multicolumn{3}{|c|}{ Teacher questionnaire } \\
\hline \multirow[t]{7}{*}{$\begin{array}{l}\text { School conditions } \\
\text { and resources }\end{array}$} & $\begin{array}{l}\text { (1) The school building needs } \\
\text { significant repair }\end{array}$ & \multirow{7}{*}{$\begin{array}{l}\text { Scale ranging from Hardly Any } \\
\text { Problems (score of at least } 10.9 \text { ) to } \\
\text { Moderate to Severe Problems (score no } \\
\text { higher than } 8.5 \text { ) }\end{array}$} \\
\hline & $\begin{array}{l}\text { (2) Teachers do not have adequate } \\
\text { workspace (e.g., for preparation, } \\
\text { collaboration, or meeting with } \\
\text { students) }\end{array}$ & \\
\hline & $\begin{array}{l}\text { (3) Teachers do not have adequate } \\
\text { instructional materials and } \\
\text { supplies }\end{array}$ & \\
\hline & $\begin{array}{l}\text { (4) The school classrooms are not } \\
\text { cleaned often enough }\end{array}$ & \\
\hline & $\begin{array}{l}\text { (5) The school classrooms need } \\
\text { maintenance work }\end{array}$ & \\
\hline & $\begin{array}{l}\text { (6) Teachers do not have adequate } \\
\text { technological resources }\end{array}$ & \\
\hline & $\begin{array}{l}\text { (7) Teachers do not have adequate } \\
\text { support for using technology }\end{array}$ & \\
\hline \multirow[t]{8}{*}{$\begin{array}{l}\text { Challenges facing } \\
\text { teachers }\end{array}$} & $\begin{array}{l}\text { (1) There are too many students } \\
\text { in the classes }\end{array}$ & \multirow{8}{*}{$\begin{array}{l}\text { Scale ranging from Few Challenges } \\
\text { (score of at least 10.3) to Many } \\
\text { Challenges (score no higher than 6.7) }\end{array}$} \\
\hline & $\begin{array}{l}\text { (2) I have too much material to } \\
\text { cover in class }\end{array}$ & \\
\hline & $\begin{array}{l}\text { (3) I have too many teaching } \\
\text { hours }\end{array}$ & \\
\hline & $\begin{array}{l}\text { (4) I need more time to prepare } \\
\text { for class }\end{array}$ & \\
\hline & $\begin{array}{l}\text { (5) I need more time to assist } \\
\text { individual students }\end{array}$ & \\
\hline & $\begin{array}{l}\text { (6) I feel too much pressure from } \\
\text { parents }\end{array}$ & \\
\hline & $\begin{array}{l}\text { (7) I have difficulty keeping up } \\
\text { with all of the changes to the } \\
\text { curriculum }\end{array}$ & \\
\hline & $\begin{array}{l}\text { (8) I have too many } \\
\text { administrative tasks }\end{array}$ & \\
\hline \multirow[t]{6}{*}{$\begin{array}{l}\text { Teaching limited } \\
\text { by student needs }\end{array}$} & $\begin{array}{l}\text { (1) Students lacking prerequisite } \\
\text { knowledge or skills }\end{array}$ & \multirow{6}{*}{$\begin{array}{l}\text { Scale ranging from Not Limited (score } \\
\text { of at least 11.4) to Very Limited (score } \\
\text { no higher than 7.4) }\end{array}$} \\
\hline & $\begin{array}{l}\text { (2) Students suffering from lack } \\
\text { of basic nutrition }\end{array}$ & \\
\hline & $\begin{array}{l}\text { (3) Students suffering from not } \\
\text { enough sleep }\end{array}$ & \\
\hline & (4) Disruptive students & \\
\hline & (5) Uninterested students & \\
\hline & $\begin{array}{l}\text { (6) Students with mental, } \\
\text { emotional or psychological } \\
\text { disabilities }\end{array}$ & \\
\hline
\end{tabular}

Note: Constructs and items from the TIMSS 2015 contextual questionnaire, reproduced from Martin et al. (2016). Items marked with an asterisk $(*)$ are reverse-coded 


\section{Appendix 2: Significance Tests on Students'Profiles and Classroom and School Environment Constructs}

\begin{tabular}{|c|c|c|c|c|}
\hline & \multicolumn{4}{|l|}{ Student profiles } \\
\hline \multirow[b]{3}{*}{ Sample Categories } & Math enthusiast & Confident & Uncertain & Nonadmirer \\
\hline & Estimate (S.E.) & Estimate (S.E.) & Estimate (S.E.) & Estimate (S.E.) \\
\hline & p-value & p-value & p-value & p-value \\
\hline & \multicolumn{4}{|l|}{ Student Bullying } \\
\hline \multirow[t]{2}{*}{ Math enthusiast } & & $1.066(0.235)$ & $1.280(0.148)$ & $0.036(0.118)$ \\
\hline & & 0.000 & 0.000 & 0.760 \\
\hline \multirow[t]{2}{*}{ Confident } & & & $0.214(0.260)$ & $-1.030(0.258)$ \\
\hline & & & 0.412 & 0.000 \\
\hline \multirow{3}{*}{ Uncertain } & & & & $-1.244(0.147)$ \\
\hline & & & & 0.000 \\
\hline & \multicolumn{4}{|c|}{ Engaging Teaching in Math Lesson } \\
\hline \multirow[t]{2}{*}{ Math enthusiast } & & $1.880(0.132)$ & $3.427(0.129)$ & $1.504(0.139)$ \\
\hline & & 0.000 & 0.000 & 0.000 \\
\hline \multirow[t]{2}{*}{ Confident } & & & $1.547(0.149)$ & $-0.376(0.171)$ \\
\hline & & & 0.000 & 0.028 \\
\hline \multirow[t]{3}{*}{ Uncertain } & & & & $-1.923(0.116)$ \\
\hline & & & & 0.000 \\
\hline & \multicolumn{4}{|c|}{ School Emphasis on Academic Success } \\
\hline \multirow[t]{2}{*}{ Math enthusiast } & & $-1.378(0.337)$ & $-1.246(0.618)$ & $-0.052(0.292)$ \\
\hline & & 0.000 & 0.044 & 0.857 \\
\hline \multirow[t]{2}{*}{ Confident } & & & $0.133(0.335)$ & $-1.326(0.199)$ \\
\hline & & & 0.692 & 0.000 \\
\hline \multirow[t]{3}{*}{ Uncertain } & & & & $-1.193(0.410)$ \\
\hline & & & & 0.004 \\
\hline & \multicolumn{4}{|c|}{ Safe and Orderly Schools } \\
\hline \multirow[t]{2}{*}{ Math enthusiast } & & $-2.104(0.557)$ & $-1.112(1.137)$ & $0.493(0.418)$ \\
\hline & & 0.000 & 0.328 & 0.238 \\
\hline \multirow[t]{2}{*}{ Confident } & & & $0.992(0.619)$ & $-2.597(0.249)$ \\
\hline & & & 0.109 & 0.000 \\
\hline \multirow[t]{3}{*}{ Uncertain } & & & & $-1.605(0.784)$ \\
\hline & & & & 0.041 \\
\hline & \multicolumn{4}{|c|}{ School Conditions and Resources } \\
\hline \multirow[t]{2}{*}{ Math enthusiast } & & $-1.133(0.587)$ & $-0.358(0.594)$ & $0.266(0.287)$ \\
\hline & & 0.054 & 0.546 & 0.353 \\
\hline \multirow[t]{2}{*}{ Confident } & & & $0.775(0.129)$ & $-1.400(0.356)$ \\
\hline & & & 0.000 & 0.000 \\
\hline \multirow[t]{2}{*}{ Uncertain } & & & & $-0.625(0.383)$ \\
\hline & & & & 0.103 \\
\hline
\end{tabular}




\begin{tabular}{l|l|l|l|l}
\hline & \multicolumn{4}{l}{ Student profiles } \\
& Math enthusiast & Confident & Uncertain & Nonadmirer \\
\cline { 2 - 5 } Sample Categories & Estimate (S.E.) & Estimate (S.E.) & Estimate (S.E.) & Estimate (S.E.) \\
\cline { 2 - 5 } & p-value & p-value & p-value & p-value \\
\hline \multirow{2}{*}{ Math enthusiast } & Challenges Facing Teachers & \multicolumn{2}{l}{} \\
\hline Confident & & $0.470(0.154)$ & $0.264(0.302)$ & $0.092(0.311)$ \\
\cline { 4 - 5 } & & 0.002 & 0.382 & 0.766 \\
\hline Uncertain & & $-0.206(0.228)$ & $0.378(0.225)$ \\
\hline & & & 0.367 & 0.093 \\
\hline
\end{tabular}

\section{References}

Abelev, M. S. (2009). Advancing out of poverty: Social class worldview and its relation to resilience. Journal of Adolescent Research, 24(1), 114-141.

Agasisti, T., Avvisati, F., Borgonovi, F., \& Longobardi, S. (2018). Academic resilience: What schools and countries do to help disadvantaged students succeed in PISA (OECD education working papers) (Vol. 167). OECD Publishing.

Bergman, L. R., \& Trost, K. (2006). The person-oriented versus the variable-oriented approach: Are they complementary, opposites, or exploring different worlds? Merrill-Palmer Quarterly, 52, 601-632.

Blossing, U., Imsen, G., \& Moos, L. (2014). Nordic schools in a time of change. In U. Blossing, G. Imsen, \& L. Moos (Eds.), The Nordic education model. Policy implications of research in education (Vol. 1, pp. 1-14). Springer.

Blossing, U., \& Söderström, Å. (2014). A school for every child in Sweden. In U. Blossing, G. Imsen, \& L. Moos (Eds.), The Nordic education model. Policy implications of research in education (Vol. 1, pp. 17-34). Springer.

Borman, G. D., \& Dowling, M. (2010). Schools and inequality: A multilevel analysis of Coleman's equality of educational opportunity data. Teachers College Record, 112(5), 1201-1246.

Broer, M., Bai, Y., \& Fonseca, F. (2019). Socio-economic achievement gaps: Trend results for education systems. In M. Broer, Y. Bai, \& F. Fonseca (Eds.), Socioeconomic inequality and educational outcomes. IEA research for education (A series of in-depth analyses based on data of the international association for the evaluation of educational achievement (IEA)) (pp. 35-70). Springer.

Bronfenbrenner, U., \& Morris, P. A. (2006). The bioecological model of human development. In W. Damon \& R. M. Lerner (Eds.), Handbook of child psychology: Vol. 1. Theoretical models of human development (6th ed., pp. 793-828). Wiley.

Doll, B. (2013). Enhancing resilience in classrooms. In S. Goldstein \& R. B. Brooks (Eds.), Handbook of resilience in children (pp. 399-409). Springer.

Doll, B., Zucker, S., \& Brehm, K. (2004). Resilient classrooms: Creating healthy environments for learning. Guilford Publications.

Eisenberg, N., Valiente, C., Fabes, R. A., Smith, C. L., Reiser, M., Shepard, S. A., et al. (2003). The relations of effortful control and ego control to children's resiliency and social functioning. Developmental Psychology, 39, 761-776. 
Erberber, E., Stephens, M., Mamedova, S., Ferguson, S., \& Kroeger, T. (2015). Socioeconomically disadvantaged students who are academically successful: Examining academic resilience cross-nationally. IEA's Policy Brief Series, 5.

Espinoza, O. (2007). Solving the equity-equality conceptual dilemma: A new model for analysis of the educational process. Educational Research, 49(4), 343-363.

Farrell, J. P. (2013). Equality of education: Six decades of comparative evidence seen from a new millennium. In R. F. Arnove, C. A. Torres, \& S. Franz (Eds.), Comparative education: The dialectic of the global and the local (4th ed., pp. 149-174). Rowman \& Littlefield Publishers.

Franklin, W. (2000). Students at promise and resilient: A historical look at risk. In M. G. Sanders (Ed.), Schooling students placed at risk research, policy, and practice in the education of poor and minority adolescents (pp. 3-16). Lawrence Erlbaum Associates, Publishers.

Geiser, C. (2013). Data analyses with Mplus. Guilford Press.

Hernandez-Martinez, P., \& Williams, J. (2013). Against the odds: Resilience in mathematics students in transition. British Educational Research Journal, 39(1), 45-59.

Hoy, W. K., Tarter, C. J., \& Hoy, A. W. (2006). Academic optimism of schools: A force for student achievement. American Educational Research Journal, 43(3), 425-446.

Jensen, F., Pettersen, A., Frønes, T. S., Kjærnsli, M., Rohatgi, A., Eriksen, A., et al. (2019). PISA 2018. Norske elevers kompetanse i lesing, matematikk og naturfag. Universitetsforlaget.

Kalender, I. (2015). An analysis of the resilient students' profile based on PISA. Journal of Measurement and Evaluation in Education and Psychology, 6(1), 158-172.

Kyriakides, L., Creemers, B., Antoniou, P., \& Demetriou, D. (2010). A synthesis of studies searching for school factors: Implications for theory and research. British Educational Research Journal, 36(5), 807-830.

Lee, V. E., \& Smith, J. B. (1999). Social support and achievement for young adolescents in Chicago: The role of school Academic Press? American Educational Research Journal, 36(4), 907-945.

Lessard, A., Butler-Kisber, L., Fortin, L., \& Marcotte, D. (2014). Analysing the discourse of dropouts and resilient students. The Journal of Educational Research, 107(2), 103-110.

Lundahl, L. (2016). Equality, inclusion and marketisation of Nordic education: Introductory notes. Research in Comparative and International Education, 11(1), 3-12.

Martin, A. J., \& Marsh, H. W. (2006). Academic resilience and its psychological and educational correlates: A construct validity approach. Psychology in the Schools, 43(3), 267-281.

Martin, A. J., \& Marsh, H. W. (2008). Academic buoyancy: Towards an understanding of students' everyday academic resilience. Journal of School Psychology, 46, 53-83.

Martin, M. O., Foy, P., Mullis, I. V., \& O’Dwyer, L. M. (2013). Effective schools in reading, mathematics, and science at fourth grade. In M. O. Martin \& I. V. Mullis (Eds.), TIMSS and PIRLS 2011: Relationships among reading, mathematics, and science achievement at the fourth grade-Implications for early learning (pp. 109-180). International Association for the Evaluation of Educational Achievement (IEA) and Lynch School of Education, Boston College.

Martin, M. O., Mullis, I. V. S., \& Hooper, M. (Eds.) (2016). Methods and Procedures in TIMSS 2015. Chestnut Hill, MA: TIMSS \& PIRLS International Study Center, Boston College.

Masten, A. S. (2014). Global perspectives on resilience in children and youth. Child Development, 85, 6-20.

Masten, A. S. (2018). Resilience theory and research on children and families: Past, present, and promise. Journal of Family Theory \& Review, 10, 12-31.

Maxwell, S., Reynolds, K., Lee, E., Subasic, E., \& Bromhead, D. (2017). The impact of school climate and school identification on academic achievement: Multilevel modeling with student and teacher data. Frontiers in Psychology, 8. https://doi.org/10.3389/fpsyg.2017.02069

Morin, A. J. S., Meyer, J. P., Creusier, J., \& Biétry, F. (2016). Multiple-group analysis of similarity in latent profile solutions. Organizational Research Methods, 19(2), 231-254.

Mullis, I. V. S., \& Martin, M. O. (Eds.). (2013). TIMSS 2015 assessment frameworks. Boston College, TIMSS \& PIRLS International Study Center.

Muthén, L. K., \& Muthén, B. O. (1998-2017). Mplus user's guide (8th ed.). Muthén \& Muthén. 
Nilsen, T., Blömeke, S., Hansen, K. Y., \& Gustafsson, J.- E. (2016). Can schools contribute to enhance equity? The answer may depend on a country's developmental level. IEA Policy Brief.

O'Brennan, L. M., \& Furlong, M. J. (2010). Relations between students' perceptions of school connectedness and peer victimisation. Journal of School Violence, 9(4), 375-391.

OECD. (2018). Equity in education: Breaking down barriers to social mobility. OECD Publishing.

OECD. (2019). TALIS 2018 results (volume I): Teachers and school leaders as lifelong learners. OECD Publishing.

Perry, L., \& McConney, A. (2010). School socio-economic composition and student outcomes in Australia: Implications for educational policy. Australian Journal of Education, 54(1), 72-85.

Pianta, R. C., \& Walsh, D. J. (1998). Applying the construct of resilience in schools: Cautions from a developmental systems perspective. School Psychology Review, 27, 407-417.

Reardon, S. F. (2011). The widening academic achievement gap between the rich and the poor: New evidence and possible explanations. In R. Murnane \& G. Duncan (Eds.), Whither opportunity? Rising inequality in schools, and children's life changes (pp. 91-116). Russel Sage Foundation Press.

Reyes, J. A., Elias, M. J., Parker, S. J., \& Rosenblatt, J. L. (2013). Promoting educational equity in disadvantaged youth: The role of resilience and social-emotional learning. In S. Goldstein \& R. B. Brooks (Eds.), Handbook of resilience in children (2nd ed., pp. 349-370). Springer.

Rutter, M. (2006). Implications of resilience concepts for scientific understanding. Annals of the New York Academy of Sciences, 1094, 1-12.

Sandoval-Hernández, A., \& Białowolski, P. (2016). Factors and conditions promoting academic resilience: A TIMSS-based analysis of five Asian education systems. Asia Pacific Education Review, 17, 511-520.

Sattler, K., \& Gershoff, E. (2019). Thresholds of resilience and within- and cross-domain academic achievement among children in poverty. Early Childhood Research Quarterly, 46, 87-96.

Skolverket. (2013). Skolverkets lägesbedömning 2013. Rapport 387. Skolverket.

Telhaug, A. O., Mediås, O. A., \& Aasen, P. (2006). The Nordic model in education: Education as part of the political system in the last 50 years. Scandinavian Journal of Educational Research, 50(3), 245-283.

Thapa, A., Cohen, J., Guffey, S., \& Higgins-D’Alessandro, A. (2013). A review of school climate research. Review of Educational Research, 83(3), 357-385.

Ungar, M., Connelly, G., Liebenberg, L., \& Theron, L. (2019). How schools enhance the development of young people's resilience. Social Indicators Research, 145, 615-627.

Wang, M., \& Degol, J. (2016). School climate: A review of the construct, measurement, and impact on student outcomes. Educational Psychology Review, 28, 315-352.

Wang, M. C., Haertel, G. D., \& Walberg, H. J. (1994). Educational resilience in inner cities. In M. C. Wang \& E. W. Gordon (Eds.), Educational resilience in inner-city America: Challenges and prospects (pp. 45-72). Lawrence Erlbaum Associates, Inc.

Wayman, J. C. (2002). The utility of educational resilience for studying degree attainment in school dropouts. The Journal of Educational Research, 95(3), 167-178.

Wiberg, M. (2019). The relationship between TIMSS mathematics achievements, grades, and national test scores. Education Inquiry, 10(4), 328-343.

Xie, C., \& Ma, Y. (2019). The mediating role of cultural capital in the relationship between socioeconomic status and student achievement in 14 economies. British Educational Research Journal, 45, 838-855.

Zhu, Y. (2018). Equity in mathematics education: What did TIMSS and PISA tell us in the last two decades? In G. Kaiser, H. Forgasz, M. Graven, A. Kuzniak, E. Simmt, \& B. Xu (Eds.), Invited lectures from the 13th international congress on mathematical education (ICME-13 monographs). Springer. 
Open Access This chapter is licensed under the terms of the Creative Commons Attribution 4.0 International License (http://creativecommons.org/licenses/by/4.0/), which permits use, sharing, adaptation, distribution and reproduction in any medium or format, as long as you give appropriate credit to the original author(s) and the source, provide a link to the Creative Commons license and indicate if changes were made.

The images or other third party material in this chapter are included in the chapter's Creative Commons license, unless indicated otherwise in a credit line to the material. If material is not included in the chapter's Creative Commons license and your intended use is not permitted by statutory regulation or exceeds the permitted use, you will need to obtain permission directly from the copyright holder. 